which is likely, then the totals shown in the table for 1975 would increase, the totals proposed for 1976 would decrease by a similar amount, and the total increase being proposed for the agency would shrink considerably.

In any event, Congress is likely to reorder the priorities in ERDA's budget a little, certainly by increasing non-nuclear appropriations and probably by reducing the amounts proposed for fission technology as well.

Even according to the OMB's analysis, however, the total amount of money that President Ford has proposed to spend on energy research and development in 1976 is more than double the total spent in $1974-\$ 1,663$ million compared with $\$ 833$ million. A question that has not been raised too openly is whether that huge surge in funds can be usefully absorbed in such a short space of time.

\section{Mining company claims sea bed}

\section{from Peter J. Smith}

THOSE who see exploitation of the ocean floor as a potential source of world conflict will take little comfort from a paid advertisement which appeared last week in The Times. For in the small-print Public Notices column, Deepsea Ventures Inc., of Delaware and Virginia, announced that "it has discovered and taken possession of ... . a deposit of North-east Pacific Ocean seabed manganese nodules."

The section of the sea bed over which the company claims "exclusive mining rights" is the area bounded by the latitudes $14^{\circ} 16^{\prime} \mathrm{N}$ and $15^{\circ} 44^{\prime} \mathrm{N}$ and longitudes $124^{\circ} 20^{\prime} \mathrm{W}$ and $127^{\circ} 46^{\prime} \mathrm{W}-$ a region lying in international waters between the Hawaiian Islands and mainland North America. Within this zone Deepsea Ventures intends to "develop, evaluate and mine the deposit and to take, use, and sell all of the manganese nodules . . . and the minerals and metals derived therefrom". As a form of "diplomatic protection and protection of investment" the company also "requests and requires [sic] states, persons, and all other commercial or political entities to respect the exclusive rights asserted".

Deepsea Ventures says that the validity of its claim is established "under existing international law as evidenced by the practice of States, the 1958 Convention on the High Seas, and the general rules of law recognised by civilised nations". In fact, the legal position is far less certain than that statement would suggest; the 1958 convention, for example, made no specific mention of any freedom to exploit the deep sea bed because at that time

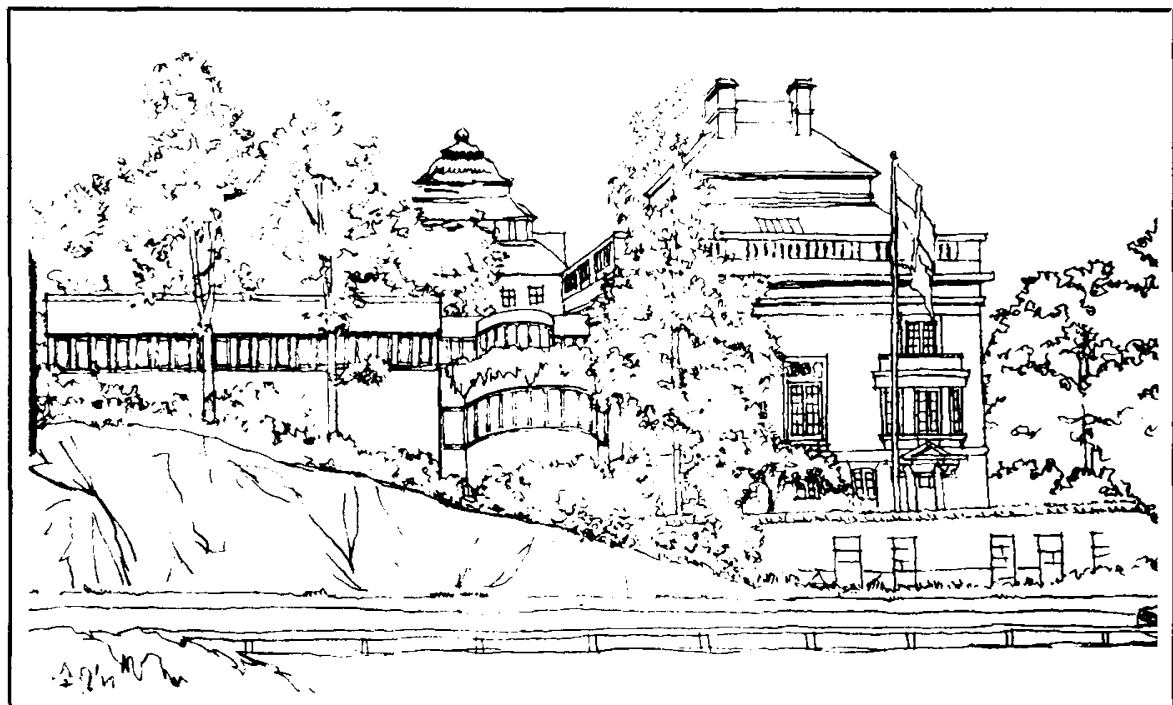

Not all of Pugwash's cries fall on deaf ears. A little known Swedish listener has offered to give substance to one of Pugwash's recent pleas: for an international institute to carry out advanced theoretical scientific studies into energy and ecology problems.

The pricked ears belong to Kjell Beijer, a Swedish businessman who last year set up the Kjell and Märta Beijer Foundation for the advancement of scientific research in Sweder. The foundation has decided that its first project will be the financing of the new institute, and is to donate Sk12 million (about $\$ 3$ million) over an initial period of 10 years for running costs and SK3 million for the construction of a building - to be attached to the Royal Swedish Academy of Sciences-in which the institute will be housed. The building should be ready by the end of 1976 .

The institute will have close links with the academy in more ways than one. The academy is to be responsible for its estaolishment, and is at present working out the details of its organisation with the Royal Swedish Academy of Engineering Sciences. The main idea is clear: the institute should be shaped along the same lines as the Stockholm International Peace Research Institute (SIPRI). An international board of scientists will be responsible for the overall planning of the work, and a director (not yet appointed) will run day-to-day activities, make suggestions to the board about new projects and carry on his own research. The actual projects will

exploitation was considered impractical.

In effect there is no international law on this matter-an omission which gives equally eminent authorities the opportunity to disagree about whether or not any form of occupation of the ocean floor is allowed. Last year's Law
Architect's sketch of the Royal Swedish Academy of Sciences building showing how it will look when the new institute is attached (at left).

be carried out by 10-15 scientists, including guest researchers who will be invited to work on problems in specific areas. Four areas have been suggested so far:

- Surveys of energy resources, including new primary sources, such as solar, geothermal and fusion energy.

- Energy and economic development, taking into account the energy problems of developing countries.

- Energy and environmental effects, including the protection of the atmosphere against thermal, chemical and nuclear damage.

- Energy in relation to other resources, for example, minerals, water and food.

The focus will be purely theoretical. No experimental work is planned. This follows from the conception of the institute as a collector, analyser and disseminator of information to governments and the growing number of groups around the world who have started to take an interest in energy questions. The most visible of the institute's activities will be conferences, workshops, symposia and publications.

And when will work begin? With luck before the building itself is ready. But even if it takes until 1977 to work up full steam, the scientists can be sure that there will still be lots of energy problems left for them to solve.

Wendy Barnaby

of the Sea Conference in Caracas failed to resolve the question. It rather looks as though Deepsea Ventures has timed its announcement to concentrate the minds of the delegates when the conference reconvenes in Geneva next month. 